\title{
Financial Impact of Large-scale Social Restriction Policy during the COVID-19 Pandemic on Entrepreneurs
}

\author{
Ingenida Hadning*, Amira Nur Alifa Fauzi \\ School of Pharmacy, Faculty of Medicine and Health Sciences, Universitas Muhammadiyah Yogyakarta, Bantul, Indonesia
}

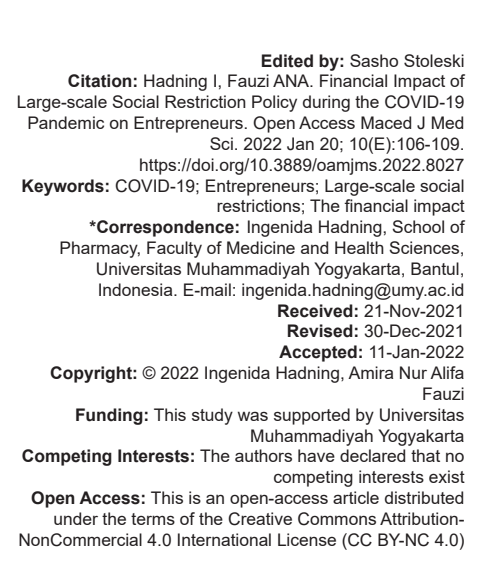

\section{Introduction}

A new disease outbreak, namely, coronavirus disease-19 (COVID-19), emerged at the end of December 2019 in Wuhan City, China. This disease arose due to infection with the Severe Acute Respiratory Syndrome Coronavirus-2 virus, which caused sufferers to experience pneumonia or acute respiratory failure characterized by symptoms such as fever, shortness of breath, coughing, sneezing, loss of sense of taste, and sense of smell [1]. This virus spreads through droplets from someone infected with COVID-19 when coughing or sneezing. Besides, it can be caused by physical contact with many people (Indonesian Ministry of Health, 2020). To reduce the spread of COVID-19, the Indonesian government made a new policy to implement large-scale social restrictions (LSSR).

The implementation of LSSR and social distancing led to enacting the Work from Home system for workers but not for entrepreneurs or traders. Therefore, LSSR has quite a significant impact on entrepreneurs and traders as LSSR could reduce the income of small and medium enterprises [2].

The research of the DPKM-UGM (2020) team stated that during the COVID-19 pandemic, 59 of the 60 respondents experienced a decrease in income, reaching $75-100 \%$ of the average income under normal conditions. Based on these problems, this study aims to determine the financial impact for entrepreneurs who underwent LSSR to prevent the spread of COVID-19. The organization for Economic Cooperation and Development (OECD, 2020) stated that during the COVID-19 pandemic, the global micro small and medium enterprises (MSMEs) underwent an economic crisis [3]. The crisis is even more severe than the one occurring in 2008. According to the Febrantara, implementing both social distancing and LSSR during the COVID-19 can influence the economy on the supply and demand viewpoint of MSMEs [4]. It leads to mass 
layoffs and decreased services and goods demand from MSMEs, which caused the enterprises not to work optimally.

\section{Methods}

This research was conducted using a nonexperimental observational method with a crosssectional approach, which measured the dependent variable and the independent variable carried out simultaneously. The research was conducted from June to July 2020 by distributing e-questionnaires for 30 days throughout Indonesia.

The population in this study were entrepreneurs in Indonesia who implemented LSSR. Sampling was carried out by the accidental sampling method for 30 days. The inclusion criteria for respondents included entrepreneurs who implemented LSSR, both male and female, aged 12-65 years and willing to be respondents. Meanwhile, the exclusion criteria were respondents who did not fill out the questionnaire completely. The instrument used in this study was a financial impact measurement questionnaire compiled by the researcher consisting of nine questions related to financial items both before and during the LSSR.

Data analysis in this study began by testing the validity and reliability of the research instrument used in this research. The validity test was carried out with the Pearson product moment correlation test method to determine the instrument's validity. The questionnaire is considered valid if the results of the $r$ count are $>r$ table. The terms and conditions of the $r$ table are 0.361 [5]. A reliability test is conducted to measure the level of consistency or trustworthiness of an instrument. The reliability test was carried out using the Cronbach's alpha method [6].

Furthermore, the data analysis related to financial impact used a descriptive method by calculating the average income before and during the LSSR and expenses before and during the LSSR. The decrease or increase in the two test groups was then calculated. The last analysis was the significance analysis between the two tested groups with the paired sample t-test method when the data were normally distributed or the Wilcoxon method when the data were not normally distributed.

\section{Results}

\section{Instrument validity and reliability tests}

The validity test of the financial impact questionnaire showed that all question items were valid with an $r$ count $>0.361$. Meanwhile, the reliability test of this questionnaire showed that the Cronbach's alpha value $>0.600$ indicating this instrument was reliable or had high consistency when it was used for repeated measurements.

\section{Respondents' characteristics}

The total number of respondents filling the questionnaire distributed for 30 days after considering the inclusion and exclusion criteria was 177 respondents. Respondents' characteristics are shown in Table 1.

Table 1: Gender distribution of the respondents

\begin{tabular}{|c|c|c|}
\hline Characteristics & $\mathrm{n}$ & $\%$ \\
\hline \multicolumn{3}{|l|}{ Gender } \\
\hline Male & 84 & 47.46 \\
\hline Female & 93 & 52.54 \\
\hline \multicolumn{3}{|l|}{ Age } \\
\hline $12-17$ years & 3 & 1.69 \\
\hline $18-25$ years & 98 & 55.37 \\
\hline $26-45$ years & 47 & 26.55 \\
\hline $46-65$ years & 29 & 16.39 \\
\hline \multicolumn{3}{|l|}{ LSSR duration } \\
\hline$<2$ weeks & 2 & 1.13 \\
\hline 2-4 weeks & 4 & 2.26 \\
\hline 5-8 weeks & 1 & 0.56 \\
\hline 9-12 weeks & 32 & 18.08 \\
\hline $13-16$ weeks & 85 & 48.02 \\
\hline >16 weeks & 53 & 29.95 \\
\hline \multicolumn{3}{|l|}{ Domicile distribution } \\
\hline Kepulauan Riau & 6 & 3.39 \\
\hline Lampung & 6 & 3.39 \\
\hline DKI Jakarta & 6 & 3.39 \\
\hline Bali & 6 & 3.39 \\
\hline West Kalimantan & 6 & 3.39 \\
\hline West Sulawesi & 6 & 3.39 \\
\hline West Papua & 6 & 3.39 \\
\hline Aceh & 5 & 2.82 \\
\hline North Sumatera & 5 & 2.82 \\
\hline West Sumatera & 5 & 2.82 \\
\hline South Sumatera & 5 & 2.82 \\
\hline Riau & 5 & 2.82 \\
\hline Jambi & 5 & 2.82 \\
\hline Bengkulu & 5 & 2.82 \\
\hline Bangka Belitung & 5 & 2.82 \\
\hline Banten & 5 & 2.82 \\
\hline West Java & 5 & 2.82 \\
\hline Central Java & 5 & 2.82 \\
\hline DI Yogyakarta & 5 & 2.82 \\
\hline East Java & 5 & 2.82 \\
\hline West Nusa Tenggara & 5 & 2.82 \\
\hline East Nusa Tenggara & 5 & 2.82 \\
\hline North Kalimantan & 5 & 2.82 \\
\hline Central Kalimantan & 5 & 2.82 \\
\hline East Kalimantan & 5 & 2.82 \\
\hline South Kalimantan & 5 & 2.82 \\
\hline Gorontalo & 5 & 2.82 \\
\hline North Sulawesi & 5 & 2.82 \\
\hline Central Sulawesi & 5 & 2.82 \\
\hline South Sulawesi & 5 & 2.82 \\
\hline Southeast Sulawesi & 5 & 2.82 \\
\hline North Maluku & 5 & 2.82 \\
\hline Maluku & 5 & 2.82 \\
\hline Papua & 5 & 2.82 \\
\hline
\end{tabular}

\section{Financial impact analysis}

The financial impact was analyzed using a descriptive analysis method to obtain the average income and expenditure decrease experienced by respondents during LSSR. The results of the financial impact analysis of the respondents are listed in Table 2. During the COVID-19 pandemic, there were changes in dominant expenditure. It caused the needs to be challenging to meet and the troubleshooting solutions on entrepreneurs. The changes are seen in Table 3. 


\section{Discussion}

\section{Respondent characteristics}

Based on data in Table 1, the number of female respondents is more significant than male, which is 93 respondents (42.54\%). According to the Bank Indonesia (2018), the total MSMEs in Indonesia reached 57.83 million businesses, $60 \%$ of which were managed by a female. Further, according to the data from the Indonesian Internet Service Providers Association or APJII (2019), it is stated that there are $91 \%$ of the 5900 samples of internet users aged $15-19$ years and $88.5 \%$ of the total sample of internet users aged 20-24 years (APJII, 2020). Therefore, the data in the table above align with APJII data where the Indonesian population with an age range of 18-25 years uses the internet more, amounting to 98 respondents $(55.37 \%)$ [7].

Table 2: The financial impact of the respondents

\begin{tabular}{llll}
\hline Category & Mean (Rp) & SE (Rp) & p-value (sig.) \\
\hline Average income before the pandemic & 12.803 .719 & 1.418 .719 & 0.00 \\
Average income during the pandemic & 9.826 .836 & 1.112 .228 & \\
Income decrease & 2.976 .271 & 471.786 & \\
Average spending before the pandemic & 5.231 .356 & 620.250 & \\
Average spending during the pandemic & 4.611 .582 & 530.767 & \\
Expenditure decrease & 619.774 & 196.788 & \\
\hline
\end{tabular}

Based on the data in this study, it showed that most respondents, which were 85 respondents (48.02\%), implemented LSSR between 13 and 16 weeks. It is directly proportional to the timing of the emergence of COVID-19 in Indonesia in early March 2020 and with the dissemination of data collection questionnaires in early June-July 2020, so that it can be estimated that between June and July 2020 was the $13-16^{\text {th }}$ week of the onset of the emergence of COVID-19 in Indonesia. Based on Table 1 , there are seven provinces that each has six respondents $(3.39 \%)$, namely, the provinces of Riau Islands, Lampung, DKI Jakarta, Bali, West Kalimantan, West Sulawesi, and West Papua. In contrast, other provinces consist of five respondents each $(2.82 \%)$.

\section{Financial impact analysis}

According to the World Bank Group (2021), the adverse effects of the pandemic are likely to dampen long-term economic growth. In Indonesia, firms lost on average at least $40 \%$ of their typical monthly sales and cut jobs. The failure of otherwise viable firms is leading to the loss of valuable intangible assets, such as supplier or customer relationships and know-how. Surviving firms are deferring productive investments. Unemployment can erode human capital and hurt future earnings. These negative effects on growth are likely to be stronger than any benefits of creative destruction induced by the crisis [8]. It will affect the circulation of money, which is very minimal in society which can cause a trade deficit [9]

Based on Table 2, the income decrease had a higher average value of Rp. 2,976,271 compared to expenditure decrease with an average of Rp. 619,774. The significance value or $p$-value was $0.00<0.05$ indicating a difference between income decrease and expenditure decrease. Besides, the result indicated that a decrease in income and expenditure significantly affected the productivity of entrepreneurs during the LSSR. Therefore, with a relatively significant decrease in income, it would be offset by a decrease in expenditure [10].

Moreover, various ways can be done to overcome economic problems resulting from the emergence of the COVID-19 pandemic in Indonesia. According to the Kemenkop-UKM (2020), several things can be done to save MSMEs in Indonesia, including the provision of tax incentives for MSMEs, the provision of social assistance to MSEs, or entrepreneurs who are most affected, the enactment of a relaxation system or credit restructuring for business actors or MSMEs, the expansion of the provision of working capital, online training, and placing the government, SOEs, and ministries as a buffer for MSME actors.

Based on Table 3, it can be seen that the most dominant expenditure is for the food category. LSSR

Table 3: The changes in dominant expenditure, the needs that are difficult to meet, and the troubleshooting solutions

\begin{tabular}{|c|c|c|c|}
\hline The changes & Category & $\mathrm{n}$ & $\%$ \\
\hline \multirow[t]{6}{*}{ Dominant expenditure change } & Food (staple food, vegetables, and raw side dishes) & 130 & 24.5 \\
\hline & Electricity & 123 & 23.16 \\
\hline & Gasoline & 102 & 19.21 \\
\hline & Instant food/drink & 76 & 14.31 \\
\hline & Data package & 73 & 13.74 \\
\hline & Health (medicine. vitamins. sanitation) & 24 & 4.52 \\
\hline \multirow[t]{8}{*}{ Expenditure that is difficult to fulfill } & Credit installment & 87 & 25.00 \\
\hline & Employee salary/holiday allowance & 84 & 24.14 \\
\hline & Cellphone credit/data package & 54 & 15.51 \\
\hline & Cost of education & 48 & 13.80 \\
\hline & Company maintenance fee & 41 & 11.78 \\
\hline & Health insurance fees & 22 & 6.32 \\
\hline & None & 11 & 3.16 \\
\hline & Social gathering dues & 1 & 0.29 \\
\hline \multirow[t]{7}{*}{ Troubleshooting solutions } & Using savings & 89 & 37.24 \\
\hline & Applying for relaxation of loan payment & 50 & 20.92 \\
\hline & Cutting employee salaries & 45 & 18.83 \\
\hline & Not doing anything & 38 & 15.90 \\
\hline & Seeking for help & 7 & 2.93 \\
\hline & Mass layoffs & 6 & 2.51 \\
\hline & Loan & 4 & 1.67 \\
\hline
\end{tabular}


and social distancing have changed the situation from all aspects of life, including significant changes to the pattern of the food supply chain in Indonesia. It is shown by the Indonesian Statistics Bureau's data related to inflation in Indonesia that food is the most volatile item from January 2019 to March 2020 [11].

In addition, during the pandemic, respondents also experienced difficulties in meeting their daily needs. Based on the data in Table 3, it can be seen that credit installments are the most difficult expenses to fulfill. LSSR has an impact on decreasing entrepreneurs' income, which causes a person to find it challenging to meet their daily needs [12].

However, various things can be done to overcome these problems. Based on Table 3, savings are the most widely chosen solution in overcoming the existing problems. The Director of Family Economic Empowerment (BKKBN, 2020) stated that in overcoming family economic problems, entrepreneurs, or family heads must first evaluate income sources where savings can still be pursued if indirectly affected. On the other hand, if a person's job is directly affected, adjustments can be made to the family budget or can use savings as an emergency fund. Besides, according to the Pakpahan (2020), saving is the right way to manage finances where the proceeds from saving can be used during an emergency or a financial crisis [13].

All in all, the implementation of social distancing and LSSR during COVID-19 can affect the economy from the demand and the supply side of MSMEs, which can lead to mass layoffs or a reduction in demand for services or goods from MSMEs, or entrepreneurs which cause a person's business not to function optimally [4].

\section{Conclusion}

Based on the results and discussions described previously, the LSSR implemented during the COVID-19 pandemic had a financial impact on entrepreneurs in the form of a significant income and expenditure decrease.

\section{References}

1. World Health Organization. Coronavirus Disease (COVID-19). Geneva: WHO; 2020. Available from: https://www.who.int/ indonesia/news/novel-coronavirus [Last accessed on 2020 Jun 07].

2. Haq I, Nasruddin R. Large-scale social restrictions (PSBB) and low-income communities. SALAM: Syar'i Journal of Social and Cultural Affairs. 2020;7(7):639-48.

3. Organisation for Economic Cooperation and Development (OECD). How's Life? 2020: Measuring Well-being; 2020. Available from: https://www.oecd.org/sdd/How-is-Life-2020highlights.pdf [Last accessed on 2021 Jan 20].

4. Febrantara D. How to handle SMEs in various countries when there is a COVID-19 pandemic. DDT Fisc Res. 2020.

5. Sugiyono S. Research Methods Quantitative, Qualitative, and R\&D Approaches; 2013.

6. Arikunto S. Research Procedures, a Practical Approach. PT Rineka Cipta; 2003.

7. Association of Indonesian Internet Service Providers (APJII). Indonesian Internet Users Almost Reach 200 Million in 2019Q2 2020; 2020. Available from: http://www.apjii.or.id/index. php/2020/11/09/siaran-pers-pengguna-internet-indonesiahampir-tembus-200-juta-di-2019-q2-2020 [Last accessed on 2020 Jun 10].

8. World Bank Group. World Bank East Asia and Pacific Economic Update October 2021: Long COVID; 2021. Available from: https://www.openknowledge.worldbank.org/bitstream/ handle/10986/36295/9781464817991.pdf\#page=16 [Last accessed on 2021 Nov 19].

9. Kurniawansyah H, Salahuddin AM, Nurhidayati S. Concept of strategic policy in dealing with economic externalities from COVID-19 in vulnerable communities in Indonesia. Indones $\mathrm{J}$ Soc Sci Humanit. 2020;1(2):130-9.

10. Imawati R. The Effect of Income, Financial Attitude, and Interna Locus of Control on Financial Behavior through Financial Literacy as an Intervening Variable (Study on Economics Students at S1 State Universities in Semarang City). Semarang: Universitas Negeri Semarang; 2020.

11. Hirawan FB, Verselita AA. Food Policy during the COVID-19 Pandemic. Indonesia: CSIS Indonesia; 2020.

12. Nurjanah A. Socio-Economic Changes Due to the COVID-19 Pandemic; 2020. Available from: https://www.kompasiana. com/asihftrn177793/5e994497d541df77e05aad82/perubahansosial-ekonomi-akibat-pandemi-covid-19 [Last accessed on 2020 Jun 05].

13. Pakpahan AK. COVID-19 and implications for micro, small and medium enterprises. J IIm Hub Int. 2020;1:59-64. 